Vol. 3 | No. 1 | 2022 | Hal. 9-16

\title{
PENGEMBANGAN INOVASI PRODUK DAN PENGGUNAAN DIGITAL MARKETING SEBAGAI UPAYA PENINGKATAN PENJUALAN UMKM MAKANAN
}

\author{
Dewi Diah Fakhriyyah*, Yuni Susanti, Siela Saadatul Laili \\ Fakultas Ekonomi dan Bisnis, Universitas Islam Malang \\ *korespondensi email: dewi_df@unisma.ac.id
}

\begin{abstract}
ABSTRAK
Di akhir tahun 2019, Dunia digemparkan dengan adanya Coronavirus Disease 2019 (Covid19). Hingga saat ini Covid-19 telah menjadi masalah dunia internasional dan memberikan implikasi terhadap ekonomi, sosial, dan politik hampir diseluruh negara, termasuk di Indonesia. Di Indonesia sendiri dampak ekonomi akibat pandemi Covid-19 juga dirasakan sektor UMKM. Salah satu UMKM yang terkena dampak pandemi adalah UMKM penjual makanan di Desa Lesanpuro, Kecamatan Kedungkandang, Malang yang selama pandemi mengalami penurunan penjualan dan pendapatan. Untuk meningkatkan penjualan dan pendapatan, kami membantu dengan memberikan sosialisasi, edukasi dan pendampingan pengembangan inovasi produk dan pemanfaatan media digital untuk pemasaran produk. Pada tahap pertama kami melakukan sosialisasi yang bertujuan untuk mengembangkan area pemasaran dengan mengenalkan digital marketing kepada pemilik UMKM supaya digital marketing tersebut dapat digunakan sebagai sarana untuk memasarkan produk yang lebih luas jangkauannya sehingga diharapkan bisa mendapatkan penghasilan yang lebih banyak. Pada tahapan yang terakhir kami juga mengedukasi tentang pentingnya menciptakan inovasi produk kreatif agar UMKM tersebut memiliki ciri khas yang dapat dengan mudah dikenal konsumen sehingga dapat menarik minat konsumen. Tahap terakhir kami melakukan pendampingan inovasi produk baik dari segi isi produk, nama produk, kemasan, dan logo usaha. Diharapkan dengan adanya kegiatan ini dapat membantu UMKM tersebut agar bisa meningkatkan pendapatannya dan bisa bertahan di tengah pandemi Covid-19.
\end{abstract}

Kata Kunci: makanan; UMKM; pandemi Covid-19; digital marketing

\section{PENDAHULUAN}

Usaha Mikro Kecil dan Menengah UMKM memiliki peran yang cukup penting dalam meningkatkan perekonomian di Indonesia. Dengan adanya UMKM maka dapat menciptakan lapangan pekerjaan bagi para pengangguran. Selain itu UMKM juga dapat dijadikan sebagai sumber pendapatan khususnya di daerah pedesaan dan rumah tangga yang perpendapatan rendah (Balitbang Kabupaten Bulelelng, 2021). Definisi UMKM diatur dalam UU Nomor 20 tahun 2008, dimana UMKM dibagi menjadi beberapa kriteria berdasarkan aset dan omset, yaitu: Usaha mikro merupakan usaha yang memiliki kekayaan bersih (aset) paling tinggi 50 juta dan omset paling banyak 300 juta. Aset yang diperhitungkan tidak termasuk tanah dan bangunan tempat usaha. Usaha kecil merupakan kelompok usahadengan kekayaan bersih setidaknya 50 juta hingga 500 juta serta memiliki nilai penjualan setidaknya 300 juta hingga 2,5 miliar. Sama halnya dengan usaha mikro, aset yang diperhitungkan tidak termasuk tanah dan bangunan tempat usaha. Usaha menegah merupakan kelompok usaha dengan aset mulai 500 juta sampai dengan 10 miliar, serta penjualan 2.5 miliar sampai dengan 50 miliar. Sama 
dengan kelompok usaha lainnya, aset yang diperhitungkan tidak termasuk tanah dan bangunan (Azzahra \& Wibawa, 2021).

Menurut Departemen Perindustrian dan Perdagangan, UMKM adalah kelompok industri kecil modern, industri tradisional, dan industri kerajinan yang mempunyai investasi modal untuk mesin dan peralatan sebesar 70 juta ke bawah dengan resiko investasi modal/tenaga kerja $\mathrm{Rp} 625.000$ ke bawah dan usahanya dimiliki oleh warga Negara Indonesia (Merina, 2019). Menurut Halim, (2020) UMKM merupakan usaha kecil yang membantu perekonomian Indonesia. Dikatakan membantu perekonomian Indonesia disebabkan karena dengan melalui UMKM akan membentuk lapangan kerja baru serta bisa meningkatkan devisa negara melalui pajak badan usaha.

Sejak tahun 2020 terjadi pandemi Covid-19 di Indonesia yang memberikan dampak dan permasalahan pada berbagai sisi kehidupan. UMKM merupakan salah satu yang terdampak dari pandemi Covid 19 yaitu terjadinya penurunan aktivitas jual beli serta distribusi yang terhambat yang mengakibatkan penurunan pendapatan UMKM (Fakhriyyah et al., 2020). Ditambah lagi dengan adanya peraturan pemerintah yaitu Pemberlakuan Pembatasan Kegiatan Masyarakat (PPKM) yang membatasi kegiatan diberbagai sektor semakin membuat perekonomian UMKM semakin lemah. Adanya PPKM dinilai akan memberi dampak ekonomi bagi usaha mikro, kecil, dan menengah (UMKM). Hal ini disampaikan oleh Peneliti Pusat Studi Ekonomi Kerakyatan (Pustek) UGM, DR. Hempri Suyatna dalam keterangan tertulisnya. Menurutnya, selama penerapan PPKM darurat hingga level 4 sampai pada 2 Agustus saja membuat banyak UMKM yang bangkrut hingga gulung tikar. PPKM dinilai menjadi ancaman serius terjadinya deindustrialisasi sektor UMKM. "Perpanjangan PPKM level 4 ini berpotensi menambah beban berat pelaku UMKM, Banyak sektor UMKM yang gulung tikar atau alih profesi". Selain itu Hempri juga mengatakan bahwa dalam kondisi pandemi sekarang ini para pelaku sektor UMKM memerlukan tidak hanya modal kerja, namun juga jejaring pemasaran serta fasilitas pengembangan bagi UMKM yang alih profesi. Banyaknya permasalahan yang terjadi pada masa pandemi covid-19 mengakibatkan UMKM mengalami berbagai kendala dan menyebabkan penurunan aktivitas jual-beli sehingga berimbas pada penurunan pendapatan (Prihatiningtias et al., 2021; Sendari, 2021).

Pendapatan yang menurun juga sangat dirasakan oleh salah satu pelaku UMKM penjual makanan di Desa Lesanpuro yang terletak di Kecamatan Kedungkandang, Malang. UMKM penjual makanan di Desa Lesanpuro merupakan salah satu UMKM yang dijadikan sebagai mata pencaharian oleh warga Lesanpuro. Hal ini karena mayoritas warganya bekerja sebagai pedagang. Karena kurangnya pengetahuan warga mengenai ilmu pemasaran menyebabkan kegiatan jual-beli masih dilakukan dengan metode konvensional/tradisional termasuk di UMKM penjual makanan yang berada di Desa Lesanpuro ini. Selain itu, pelaku UMKM penjual makanan tersebut juga masih menjual produk tanpa adanya inovasi dimana kurang adanya ciri khas dan keunikan yang dimiliki sehingga menyebabkan terhambatnya pemasaran karena kurangnya daya tarik konsumen dan pada akhirnya masih kesulitan dalam menghadapi persaingan. Selama masa PPKM, penjualan produk makanan UMKM di Lesanpuro mengalami penurunan signifikan.

Dari permasalahan tersebut maka diperlukan perubahan sistem penjualan konvensional yang biasa digunakan oleh UMKM makanan di Lesanpuro menjadi sistem penjualan yang dapat meningkatkan pendapatan khususnya di era pandemi seperti ini. Hal ini yang membuat kami merasa perlu untuk melakukan sosialisasi dan edukasi sistem penjualan dan pemasaran menggunakan digital marketing pada pelaku usaha penjual makanan di Lesanpuro. 
Chaffey \& Ellis-Chadwick (2016) menyatakan bahwa digital marketing merupakan aplikasi dari internet dan berhubungan dengan teknologi digital dimana didalamnya berhubungan dengan komunikasi tradisional untuk mencapai tujuan pemasaran. Hal tersebut dapat dicapai untuk meningkatkan pengetahuan tentang konsumen seperti profil, perilaku, nilai, dan tingkat loyalitas, kemudian menyatukan komunikasi yang ditargetkan dan pelayanan online sesuai kebutuhan masing-masing individu. Menurut Chaffey \& EllisChadwick (2016) pada dasarnya digital marketing adalah kegiatan pemasaran yang menggunakan media digital dengan menggunakan internet yang memanfaatkan media berupa web, social media, e-mail, database, mobile/wireless, dan digital tv guna meningkatkan target konsumen dan untuk mengetahui rofil, perilaku, nilai produk, serta loyalitas para pelanggan atau targetkonsumen untuk mencapai tujuan pemasaran.

Dari penjelasan di atas dapat disimpulkan bahwa pada dasarnya digital marketing merupakan kegiatan pemasaran yang menggunakan media digital dengan mengunakan internet yang memanfaatkan media berupa web, social media, e-mail, database, mobile/wireless, dan digital tv guna meningkatkan pemasaran serta target konsumen sehingga bisa berimbas pada peningkatan pendapatan. Pemanfaatan digital marketing dianggap cara paling efektif untuk saat ini sebagai salah satu pemasaran bagi semua jenis usaha, tidak terkecuali untuk UMKM. Sebab, meskipun bisnis dijalankan dengan skala cukup kecil, menentukan strategi promosi yang tepat tetap perlu dilakukan agar bisnis selalu berkembang. Salah satu contoh digital marketing adalah upaya pemasaran online dengan menggunakan internet seperti Facebook, WhatsApp, Instagram, dll dimana penjual bisa berkomunikasi dengan calon konsumen di dunia maya. Kepala Program Studi Bio Kewirausahaan i3I School of Business (iSB), Reni Saraswati, menyatakan bahwa pemasaran menggunakan media digital merupakan strategi yang ampuh dalam meningkatkan efektifitas serta keuntungan bagi penggunanya. Berdasarkan data dari Statista di awal tahun 2021, hampir 60\% dari total populasi dunia adalah pengguna internet. Dari populasi tersebut, Indonesia menempati urutan ke 3 sebagai pengguna internet terbanyak di dunia (Sembiring, 2021). Hal ini dapat dimanfaatkan pengusaha tak terkecuali UMKM makanan Cemal Cemil di Desa Lesanpuro untuk menjangkau pelanggan tanpa ada batasan lokasi dan waktu dalam mempromosikan serta memberikan layanan bisnis secara online. Dengan menggunakan digital marketing diharapkan UMKM makanan Cemal Cemil Desa Lesanpuro dapat dikenal masyarakat lebih luas yang akan berdampak pada peningkatan penjualan.

Selain pengenalan digital marketing, edukasi mengenai inovasi produk kreatif pada produk UMKM makanan desa Lesanpuro juga sangat penting dilakukan supaya dapat memberikan nilai tambah produk tersebut dan bisa lebih menarik minat konsumen. Terkadang pasar mengalami kejenuhan atas suatu produk, sehingga diperlukan pembaharuan ataupun inovasi produk agar dapat menarik kembali minat pasar.

Inovasi produk menunjukkan ada pengembangan dan pengenalan produk baru atau pengembangan produk baik perubahan desain, komponen dan arsitektur produk itu sendiri (Alkachvi, 2018). Inovasi produk juga terbukti dapat mempengaruhi kepuasan konsumen (Afriyani \& Muhajirin, 2021).

Tujuan dilakukannya sosialisasi dan edukasi mengenai pemasaran melalui digital marketing dan berinovasi produk kreatif pada pelaku UMKM makanan Desa Lesanpuro yaitu untuk meningkatkan pengetahuan masyarakat khususnya pemilik UMKM makanan Desa Lesanpuro tentang teknik pemasaran online guna memperlancar arus perdagangan di Desa Lesanpuro, khususnya di era pandemi seperti sekarang dimana masyarakat dituntut untuk lebih memanfaatkan teknologi yang ada guna mengurangi aktivitas di luar rumah.Selain itu tujuan pengenalan inovasi produk kreatif dimaksudkan agar UMKM tersebut memiliki ciri khas produk sehingga dapat dengan mudah dikenal konsumen sehingga dapat menarik 
minat konsumen yang nantinya berdampak terhadap peningkatan pendapatan dan dapat digunakan sebagai keunggulan bersaing.

\section{METODE}

Dalam menjalankan kegiatan sosialisasi dan edukasi bagi pelaku UMKM makanan di Desa Lesanpuro ini, kami telah menyusun beberapa program kerja yang berfokus pada tujuan utama yaitu untuk meningkatkan penjualan produk sehingga berdampak pada peningkatan pendapatan. Sebelum melakukan kegiatan, kami melakukan survey terlebih dahulu serta telah diberi izin oleh pemilik UMKM makanan Cemal Cemil dan Kepala Desa setempat untuk melakukan kegiatan tersebut. Setelah itu, kami segera menjalankan program kerja yang telah kami susun dengan tetap memperhatikan protokol kesehatan. Metode yang kami gunakan dalam sosialisasi ini adalah ceramah dan pendampingan. Adapun beberapa pokok permasalahan yang dibahas dalam sosialisasi yang kami lakukan yaitu: (1) Pentingnya mempertahankan dan mengembangkan bisnis di tengah pandemi Covid-19; (2) Pemasaran produk melalui digital marketing; (3) Edukasi dan implementasi inovasi produk kreatif guna mengembangkan perekonomian UMKM di masa pandemi Covid19.

Adanya peraturan pemerintah supaya tidak membuat kerumunan di masa pandemi Covid-19, kami melakukan kegiatan sosialisasi di UMKM desa Lesanpuro dengan melakukan pembatasan pertemuan secara langsung. Dalam satu minggu kami hanya melakukan pertemuan dengan pemilik UMKM selama dua hari untuk menghindari penularan Covid-19. Akan tetapi kami tetap melakukan komunikasi melalui media sosial untuk mendukung keberhasilan kegiatan sosialisasi dan edukasi yang kami lakukan sehingga diharapkan bisa membantu mengembangkan perekonomian UMKM makanan Cemal Cemil di Desa Lesanpuro tersebut.

\section{HASIL DAN PEMBAHASAN}

Setelah beberapa hari kami menjalankan program kerja, kami bisa mengamati bahwa masih kurangnya pengetahuan tentang cara berbisnis pada pemilik UMKM makanan Cemal Cemil di Desa Lesanpuro. Selama ini pelaku UMKM tersebut hanya memasarkan produknya secara offline atau berjualan secara langsung di rumah tanpa adanya pemasaran secara online melalui media sosial sehingga jangkauan pemasaran produk sangat terbatas. Serta kurang adanya inovasi produk kreatif juga menjadi kendala dalam meningkatkan penjualan produk di UMKM tersebut.

Tahap pertama tepatnya pada minggu pertama tanggal 4 Agustus 2021, kami melakukan sosialisasi akan pentingnya mempertahankan dan mengembangkan bisnis di masa pandemi Covid-19. Dalam sosialisasi tersebut, kami melakukan pendekatan dan memberikan penjelasan yang jelas supaya lebih bisa dipahami oleh pelaku UMKM makanan Cemal Cemil di Desa Lesanpuro. Penggunaan tutur kata yang santai dan bahasa sehari-hari yang sopan pada saat sosialisasi menjadikan pelaku UMKM mudah mengerti dan lebih paham apa arti bisnis yang sesungguhnya serta pentingnya mempertahankan dan mengembangkan bisnis di tengah pandemi Covid-19. Antusiasme pelaku UMKM tersebut sangat mendukung kesuksesan kegiatan pada tahap pertama ini walaupun yang awalnya pelaku UMKM tersebut sempat mengeluh akibat penurunan penjualan secara drastis di masa Pandemi Covid-19. 


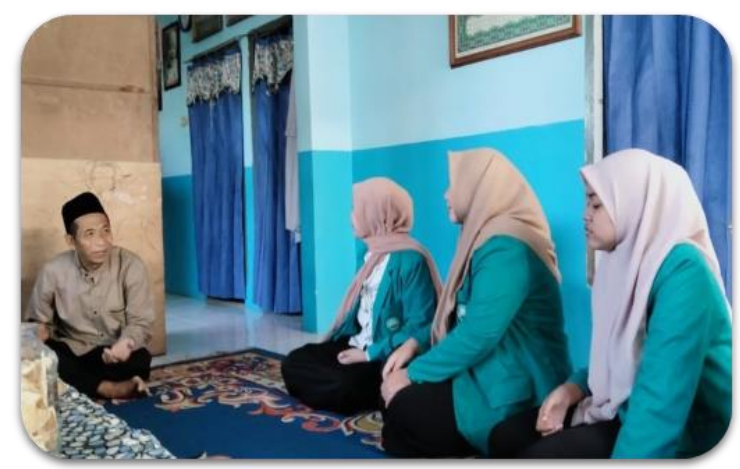

Gambar 1. Proses sosialisasi akan pentingnya mempertahankan dan mengembangkan bisnis di masa pandemi Covid-19 di Desa Lesanpuro

Tahap kedua yaitu sosialisasi mengenai digital marketing yang kami laksanakan pada minggu ke-2 tepatnya pada tanggal 9 Agustus 2021 sampai tanggal 10 Agustus 2021. Pada tahap ini kami mulai menjelaskan tentang apa itu digital marketing dan seberapa pentingnya digital marketing dalam dunia bisnis terutama di saat covid-19 seperti ini, dimana semua orang dituntut untuk paham dan bisa memanfaatkan kecanggihan teknologi yang ada. Selain itu, kami juga melakukan bimbingan langsung terhadap pelaku UMKM makanan Cemal Cemil di Desa Lesanpuro untuk langsung menerapkan digital marketing supaya lebih paham dan bisa mempraktekkan secara langsung mengenai manfaat digital marketing. Dengan mengenalkan transformasi digital diharapkan pelaku UMKM dapat mengembangkan usahanya melalui media digital supaya lebih dikenal masyarakat luas. Dalam sosialisasi kami juga memberikan saran dalam menjalankan sosial media marketing yaitu: (1) Aktif dalam bersosial media seperti Facebook, Instagram, WhatsApp.; (2) Membuat konten yang bisa menarik minat konsumen; (3) Menyajikan produk yang inovatif.

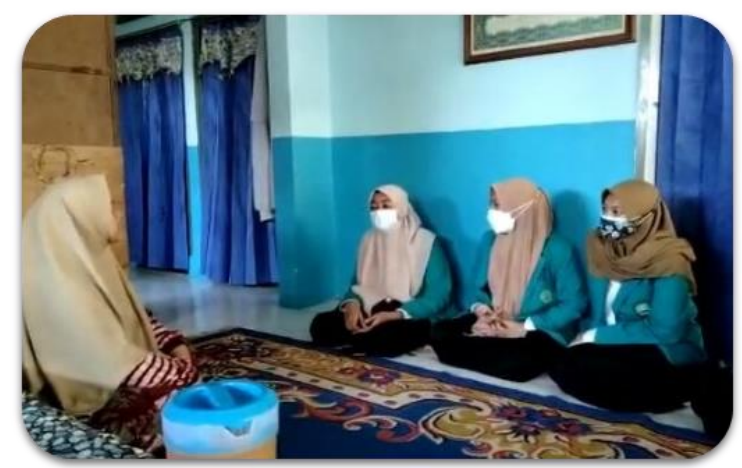

Gambar 2. Proses sosialisasi mengenai transformasi digital marketing UMKM di Desa Lesanpuro

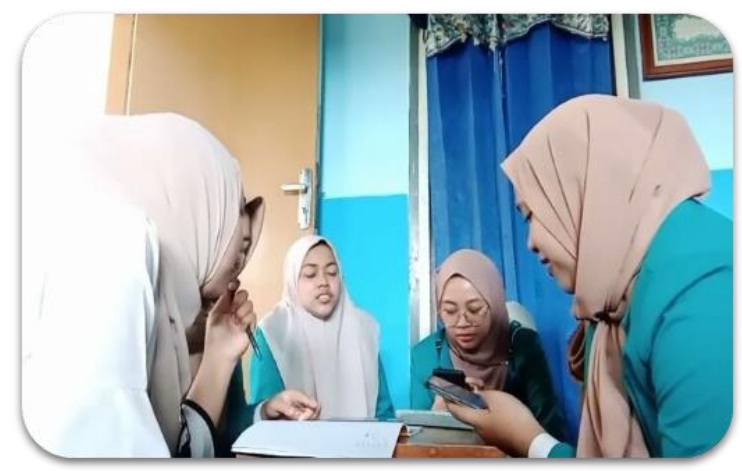

Gambar 3. Proses pembuatan akun diberbagai media sosial seperti Facebook dan Instagram. Serta membuat konten yang menarik sebagai sarana pemasaran secara online 
Pada tahap terakhir yaitu edukasi dan implementasi inovasi produk kreatif guna mengembangkan perekonomian UMKM di masa pandemi Covid-19 yang kami laksanakan dengan lima kali pertemuan tepatnya pada minggu ke-2 sampai minggu ke-4. Hasil produk selama ini yang terkesan sederhana membuat produk terlihat kuno dan tidak menarik sehingga masih lemah dalam persaingan di zaman yang serba modern ini. Ditambah lagi tanpa adanya identitas membuat produk tersebut jarang dikenal masyarakat. Sehingga kami berinisiatif untuk mengenalkan beberapa inovasi pada produk UMKM makanan Cemal Cemil di Desa Lesanpuro supaya terdapat ciri khas dan bisa memberikan nilai lebih pada produk. Beberapa inovasi tersebut diantaranya yaitu:

1. Membuat logo usaha, sehingga bisa menjadi simbol atau lambang dari usaha tersebut serta usaha dan produknya bisa lebih dikenal masyarakat.

2. Menambah varian topping pada produk dan memberi nama produk dengan nama yang lebih modern Contohnya mie petir, mie gledek, mie mendung, dll supaya masyarakat lebih penasaran dan tertarik untuk membeli.

3. Pengemasan produk yang lebih menarik. Yang awalnya produk hanya menggunakan kemasan dari styrofoam, kini kami berinisiatif untuk menggunakan kemasan lebih modern yaitu dari kertas berlapis plastik yang lebih terlihat menarik dimana tanpa adanya tambahan biaya produksi sehingga tidak mengurangi keuntungan. Selain itu, pada kemasan juga terdapat logo dan jenis menu yang ditawarkan. Sehingga pada saat awal melihatnya terkesan sangat menarik.

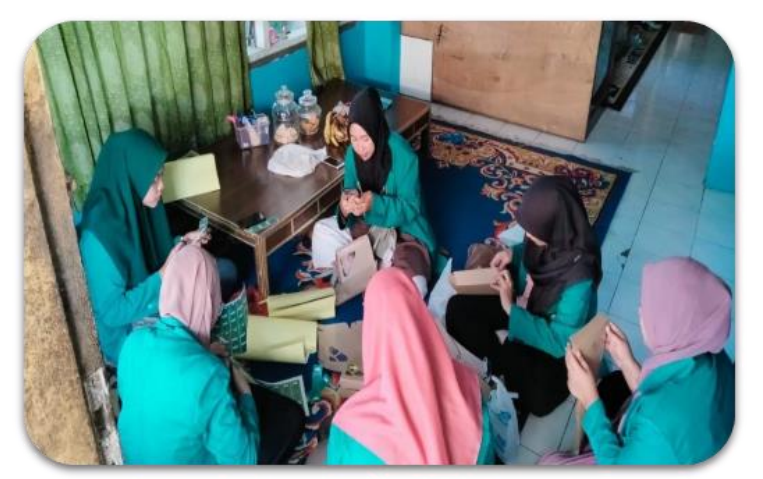

Gambar 4. Proses pembuatan logo UMKM makanan Cemal cemil di Desa Lesanpuro

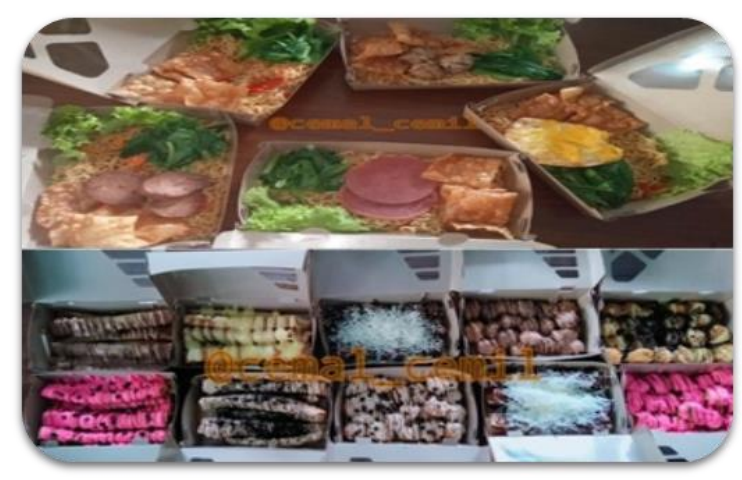

Gambar 5. Produk dengan berbagai varian topping 


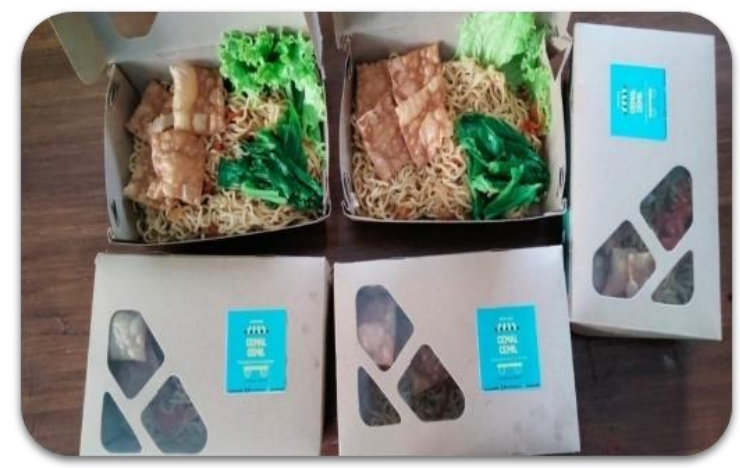

Gambar 6. Inovasi kemasan produk yang lebih modern dan menarik

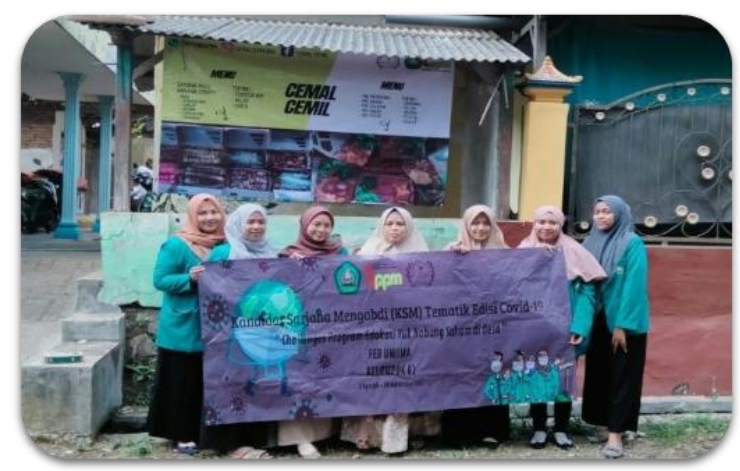

Gambar 7. Foto bersama di warung Cemal Cemil

\section{KESIMPULAN}

Selama ini pelaku UMKM makanan Cemal Cemil yang terletak di Desa Lesanpuro, Kecamatan Kedungkandang, Malang masih belum sepenuhnya memahami tentang cara mengembangkan bisnis yang tepat, ehingga sulit untuk mengembangkan usahanya ditambah dengan adanya pandemi Covid-19 dimana membuat sebagian besar perekonomian mengalami penurunan. Melihat hal tersebut kami berinisiatif untuk melakukan sosialisasi dan edukasi mengenai bisnis UMKM terutama dalam hal pemasaran produk, dimana kami mulai mengenalkan digital marketing hingga inovasi produk kreatif. Setelah diadakannya kegiatan ini pelaku UMKM bisa menjadi lebih paham tentang pentingnya digital marketing sebagai sarana pemasaran dan berinovasi produk kreatif guna menarik minat konsumen. Dalam memaksimalkan program kerja, kami menghadapi beberapa kendala seperti faktor waktu yang sangat singkat, biaya, dan keterbatasan ruang gerak di masa pandemi Covid-19 seperti saat ini. Sehingga kami berharap untuk pengabdian di masa mendatang dapat memberikan wawasan yang lebih luas lagi dalam meningkatkan promosi produk dengan mengikuti perkembangan pasar dan dunia digital serta dapat merambah lebih banyak UMKM.

\section{UCAPAN TERIMA KASIH}

Kami mengucapkan terima kasih kepada LPPM UNISMA yang sudah memberikan kesempatan kepada kami untuk melakukan kegiatan KSM-TEMATIK dan Kepala Desa Lesanpuro, Kecamatan Kedungkandang, Malang yang telah memberi izin kepada kami untuk melakukan pengabdian masyarakat, serta pemilik UMKM makanan Cemal Cemil yang telah memberikan izin pada kami untuk membantu memberikan sosialisasi serta edukasi mengenai inovasi produk kreatif dan digitalisasi marketing. 


\section{DAFTAR RUJUKAN}

Afriyani, Y., \& Muhajirin. (2021). Pengaruh Inovasi dan Kreativitas Terhadap Kepuasan Konsumen pada UKM Dina Kelurahan Ntobo. Target: Jurnal Manajemen Dan Bisnis, $3(1)$,

https://journal.universitasbumigora.ac.id/index.php/target/article/view/1175

Alkachvi, M. D. (2018). Pengaruh Kreativitas dan Inovasi Produk terhadap Keberhasilan Usaha (survey pada Pengusaha Sentra Sangkar Burung Sukohaji Bandung). Universitas Komputer Indonesia.

Azzahra, B., \& Wibawa, I. G. A. R. P. (2021). Strategi Optimalisasi Standar Kinerja UMKM sebagai Katalis Perekonomian Indonesia dalam Menghadapi Middle Income TRAP 2045. INSPIRE Journal Economic and Development Analysis, 1(1), 75-86. https://ejournal.uksw.edu/inspire/article/view/4856

Balitbang Kabupaten Bulelelng. (2021). Dampak Pandemi Covid 19 Terhadap UMKM di Buleleng. https://balitbang.bulelengkab.go.id/informasi/detail/artikel/76-dampakpandemi-covid-19-terhadap-umkm-di-buleleng

Chaffey, D., \& Ellis-Chadwick, F. (2016). Digital Marketing (6th ed.). Pearson Education Limited.

Fakhriyyah, D. D., Wulandari, Y., \& Kharisma, C. (2020). Sosialisasi digital marketing dan inovasi produk pada ukm gula merah guna mempertahankan ekonomi di masa pandemi covid-19. Jurnal Pembelajaran Pemberdayaan Masyarakat (JP2M), 1(4), 311-317. https://doi.org/10.33474/jp2m.v1i4.8691

Halim, A. (2020). Pengaruh Pertumbuhan Usaha Mikro, Kecil dan Menengah terhadap Pertumbuhan Ekonomi Kabupaten Mamuju. GROWTH: Jurnal Ilmiah Ekonomi Pembangunan, 1(2), 157-172. https://stiemmamuju.ejournal.id/GJIEP/article/view/39

Merina, N. (2019). Pengertian UKM \& UMKM? Bagaimana Menjadi Usaha Kecil Menengah di Indonesia. GOukm.Id. https://goukm.id/apa-itu-ukm-umkm-startup/

Prihatiningtias, Y. W., Prabandari, S. P., Cahaya, D. N., Kusumadewi, A. W., Anggraeni, O. L., Nisa, K., Rizkiyah, A., \& Arasy, F. H. (2021). Peningkatan pengetahuan aspek perpajakan dan kualitas pengelolaan produk pada kelompok UMKM. Jurnal Inovasi Hasil $\begin{array}{lll}\text { Pengabdian } \quad \text { Masyarakat } & \text { (JIPEMAS), }\end{array}$ https://doi.org/10.33474/jipemas.v4i1.8674

Sembiring, K. (2021). Pakar Kewirausahaan Ini Beberkan Manfaat Belajar Digital Marketing dalam Bisnis.

SindoNews.Com. https://edukasi.sindonews.com/read/437216/211/pakar-kewirausahaan-inibeberkan-manfaat-belajar-digital-marketing-dalam-bisnis-1621937107

Sendari, A. A. (2021). Perpanjangan PPKM Ancam Pelaku UMKM, Ini Kata Ahli. Liputan 6. https://hot.liputan6.com/read/4623088/perpanjangan-ppkm-ancam-pelaku-umkmini-kata-ahli 